\title{
WRITING IN SCHOOL CONTEXTS
}

\author{
PETER SMAGORINSKY \\ The University of Georgia, Department of Language and Literacy Education
}

\section{INTRODUCTION}

In 1963 the National Council of Teachers of English (NCTE) published Braddock, Lloyd-Jones, and Schoer's Research in Written Composition, a review of writing research covering the first writing studies in the early part of the century through 1962. In 1986 the National Conference on Research in English (NCRE) and the Educational Resources Information Center (ERIC) copublished George Hillocks's Research on Written Composition: New Directions for Teaching, a volume that reviewed writing research from 1963-1983. The articles included in this special theme issue of L1-Educational Studies of Language and Literature on Writing in School Contexts report the findings of Marilyn Chapman, George Hillocks, and Russel Durst on composition in school settings covering 1984-2003 (for an expanded review of composition studies during this period, see the contributions to Smagorinsky, 2006).

L1 - Educational Studies in Language and Literature (2006), 6 (2), p. 1-6

(C) International Association for the Improvement of Mother Tongue Education

Correspondence concerning this article should be directed to Peter Smagorinsky, The University of Georgia, College of Education, 125 Aderhold Hall, Athens, GA 30602 ,. Electronic mailmay be sent to smago@uga.edu 
The review articles in this special theme issue focus on school-based writing instruction, with elementary, secondary, and post-secondary education the emphasis of the three articles. The authors were asked to adhere to the following guidelines:

- The reviews focus on published research. Previous volumes (Braddock et al., 1963; Hillocks, 1986) have included unpublished dissertations and conference presentations. The present volume focuses instead on research that has survived a rigorous review process. The purpose of this limitation is twofold: to help manage the amount of work covered in this expanded volume (Hillocks's bibliography alone covered 102 pages) and to eliminate from consideration those studies too flawed to be published in a field that has seen a great proliferation of publication opportunities.

- While authors were encouraged to include as much international research as possible, this effort was limited by access to more global composition research. As a consequence, the reviews focus on research published in the English language and, while including attention to work from outside North America, is most comprehensive in its coverage of research published in U.S.-based journals and books.

- In their reviews of composition, authors include not only writing but other mediating tools (e.g., drawing, performance, computers) that are used for composition. The previous two reviews have focused solely on writing, with that focus specifically named in the books' titles. The last twenty years have seen broader conceptions of literacy outlined in composition research that are reflected in this set of review articles.

- Each article includes attention to a common set of concerns. Regardless of organizing principal, each author includes the following:

1) Research published between 1984 and 2003.

2) A review of the theories that have motivated research in this area, showing trends over time and situating these trends within broader philosophical, political, ontological, epistemological, and theoretical perspectives influencing both scholarship and society at large.

3) A review of research methods that have been used in this area, looking for links between theoretical frameworks and investigative approaches.

4) A review of research findings and conclusions.

5) A review of implications for theory, practice, policy, etc. argued by researchers.

6) A complete bibliography of research reviewed during this period.

Marilyn Chapman opens with a review of school-based research conducted in the primary grades. With schools now varying greatly in the grade level break between elementary and middle school, the determination of what is covered in this chapter is on what kind of school the research is situated in. Research that identifies the site as pre-K, kindergarten, preschool, elementary school, or primary school is included in this review. Typically, these sites have relatively few teachers, each of whom teaches a variety of subjects. While language arts lessons are often the focus of such studies, research may also investigate writing in subject areas (e.g., science) and include attention to other modalities (e.g., relations between drawing and writing). 
Chapman finds that the "social turn" in writing research has made research in this area more complex because no single approach is best for all students; rather, the social and cultural contexts of classrooms suggest that instruction should take into account factors from learners' experiences and social practices and build on them, rather than expecting all students to respond identically to the same teaching. Ironically, this conclusion stands at odds with the federally mandated No Child Left Behind legislation, which takes a reductive approach to literacy and seeks a homogenized literacy performance from all students, regardless of cultural background.

George Hillocks, Jr., reviews research that takes place at sites identified as middle school, junior high school, secondary school, and high school. In these sites English emerges as a distinct discipline and core subject area, taught by a specialist with specific credentials for teaching the subject. Hillocks's most daunting conclusion is that, because much secondary school writing is taught in the context of testing and assessment mandates, writing instruction has not yet realized its potential. Indeed, because writing assessments tend to reward essays written according to a five-paragraph model (a form routinely believed by writing theorists to limit writers more than it enables them), the many publications promoting more open-ended, exploratory, inquiry-oriented writing are having less effect on the teaching of writing than they might without the problem that many teachers teach to a theoretically illinformed test.

Russel K. Durst reviews composing in postsecondary educational settings, including any formal site of education beyond high school: two-year colleges, fouryear colleges and universities, graduate studies at universities, adult continuing education, and distance education. While sharing some concerns of writing at other levels of schooling, writing instruction in these sites analyzes problems that are unique in terms of schooling: transitions to higher education and attendant issues in first-year composition, socialization into disciplinary communities and practices, and so on. Durst concludes that writing research at the postsecondary level has lost its imperative and direction at the dawn of the $21^{\text {st }}$ century. Most composition instructors have been persuaded, he argues, that the "current-traditional" approach that focused on the reproduction of classic forms is now obsolete. While limiting for students, this monolith provided an institution against which more provocative theories could be launched. Durst argues that without a clear antagonist, composition theorists are less focused now than they were in 1984 and would benefit from an antagonistic position against which to argue - much as the No Child Left Behind legislation has helped to galvanize elementary school composition researchers against its literalist orientation and argue for more expressive and imaginative writing opportunities for younger students.

Taken as a whole, these reviews indicate the "social turn" that has occurred in composition studies; that is, the move away from conceiving writers as individuals struggling to put pen to paper (or fingers to keyboard), and toward an understanding of the social, cultural, and historical factors that contribute to the setting in which writing and writing instruction take place. As such, writing research and instruction have been less concerned with the "best practices" that preoccupied Braddock et al. (1963) and Hillocks (1986) and have begun to interrogate a set of questions that might be reduced to the following query: Why is this happening here and now? By 
considering this question, researchers may consider why a particular instructional practice may work in an affluent suburb but find resistance in an impoverished urban classroom, or flourish for Ms. Smith in Room 203 but flop for Ms. Jones in Room 204. This more nuanced, contextual approach has made composition studies more complex and provocative, and sets the stage for the next two decades of writing research.

\title{
REFERENCES
}

Braddock, R., Lloyd-Jones, R., \& Schoer, L. (1963). Research in written composition. Champaign, IL: National Council of Teachers of English.

Hillocks, G., Jr. (1986). Research on written composition: New directions for teaching. Urbana, IL: National Conference on Research in English/ERIC Clearinghouse on Reading and Communications skills.

Smagorinsky, P. (Ed.). (2006). Research on composition: Multiple perspectives on two decades of change. New York: Teachers College Press and the National Conference on Research in Language and Literacy.

\section{TRANSLATION INTO CHINESE (SHEK KAM TSE)}

\author{
《学校写作在第一语言的语文及文学教育研究》特刊简介 \\ Peter Smagorinsky \\ 乔治亚洲大学, 语文及文学教育学系
}

(The University of Georgia, Department of Language and Literacy Education ) 摘要

本特刊 一《学校写作在第一语言的语文及文学教育研究》, 刊载了三篇 有关Chapman, George Hillocks 及Russel Durst 在1984 至2003 年, 分别对小 学、中学、大专的学校为本写作教学的回顾。这些回顾都是根据严谨和精密的 研究来撰写的。研究本身跟学术界、社会甚至全球都有密切的关系, 引起很多 不同层面的讨论, 也能为未来二十年的写作研究, 定下基础。

\section{引言}

1963 年，全国英文教师议会（The National Council of Teachers of English, NCTE ）出版了Braddock, Lloyd-Jones 及Schoer 所著的《写作研究》

(Research in Written Composition), 回顾了由世纪初第一次直至1962 年有关 写作的研究。1986 年, 全国英文研究研讨会 (The National Conference on Research in English, NCRE) 和教育研究信息数据库（The Educational Resources Information Center, ERIC) 合作, 出版了 George Hillocks 的 《写作研究: 教学 新方向》（Research on Written Composition: New Directions for Teaching）。这 本书回顾了1963 至1983 年期间进行的写作研究。所有刊载于本特刊 - 《学 校写作在第一语言的语文及文学教育研究》的文章, 报告了Chapman, George Hillocks \& Russel Durst 在1984 至2003 年, 对学校写作的研究（对此期间宏观 
的回顾，可参阅Smagorinsky（2006））。

三篇刊载于本特刊的回顾文章, 分别集中检视了小学、中学、大专的学校 为本写作教学。作者需要遵守下列的出版指引:

- 回顾的文章, 需要集中在已出版的研究。以前的期次 (Braddock et al., 1963; Hillocks, 1986）则包含了未出版的论文和会议报告。本特刊集中 回顾那些严谨和精密的研究。这个限制有双重的作用: 帮助管理本特刊 的工作量 (单是Hillocks 的参考书目, 便有 102 页), 以及减除存有太 多缺点的研究的出版, 以提高出版机会.

- 虽然我们鼓励作者的论文, 尽量加入多些国际性的研究, 但他们仍应集 中回顾那些全球关注的写作研究上。这些回顾主要为以英文发表的研 究, 并广泛地包含美国的期刊和书籍, 以及北美以外的研究成果。

- 在文献回顾中, 不但包括写作, 而且包括其它间接的写作工具, 例如: 绘图、表演、计算机。之前的两个回顾只集中在写作, 并明确地把这焦 点表明在书名上。在最近的二十年里, 从写作研究中可以看出对文学有 更广的概念, 这反映在这组回顾章中。

- 每篇文章都包括了一些常见的关注事情, 包括以下几项:

1) 出版于1984 至2003 年之间的研究。

2) 一个激发这方面研究的理论的回顾, 并可以展示在该段时间内的趋势, 以 及展示这些对学术界和社会大大影响、置于更广的哲学、政治学、本体 论、认识论和推论的趋势。

3) 一个有关获采用研究方法的回顾, 并找出理论框架和调查方式的关连。

4) 一个研究所得和结论的回顾。

5) 一个研究者对理论、实践、政策等言外之音争论的回顾。

6) 在这段期间的一个完整研究参考书目。

Marilyn Chapman 曾回顾在小学进行的学校为本研究。由于小学和中学的分别 很大, 故在决定本章的内容时, 要先选定研究在甚么类型的学校进行。这个回 顾, 已界定了幼儿园、幼儿园、学前教育或小学。相对地, 这些研究领域的教 师人数较少, 每位教师都教多个科目。尽管研究的焦点多集中在语言课, 但研 究其实也应该包括跨学科的写作（例如: 科学) , 和其它写作形式 (例如: 绘 图和写作之间的关系）。

Chapman 认为写作研究中的社会转化, 令这方面的研究更复杂, 因为没有单 一的方法适合所有学生的; 课室的社会和文化背景, 学习者的经验和社会实 践, 都会影响写作, 并不只是教学法的问题。讽刺的是, 这结论与美国联邦政 府的教育法规 一《没有儿童被遗下》不相符, 这法规忽略了文化背景, 对全 体学生要求相同的语文能力表现。

George Hillocks, Jr 检讨了在中学、初中和高中进行的研究。在这些学校里, 英文成为一个专科和核心课程, 并由一个受过专业训练的专家任教。Hillocks 
提出最令人不安的结论是: 因为大多数中学作文是以测验或评估为目的, 因 此, 写作教学未能发挥学生应有的潜能。事实上, 很多评论都赞赏以五段模式 的写作教学法 (实际上, 很多写作理论专家认为, 这种教学模式局限了学生的 能力, 多于协助他们发展写作能力) 。大部分的著作都认为写作教学应该是开 放式、探索式的和学生为本的, 会有更佳的教学效果。

Russel K. Durst 检讨中学阶段后的写作教学, 包括中学以上, 任何正式的教 育: 两年制学院、四年制学院、大学、大学研究院、成人教育和遥距教育。他 的回顾关注以下的论题：教育的特殊性、中学与高等教学的衔接、大学一年级 写作课出席率问题、社会化和纪律化的问题等。

Durst 总结大专领域的写作研究, 已失去了 21 世纪的方向。大部分教师都被游 说放弃学习古典范文。这个回顾提供一些刺激性的理论, 可以应用到学校里。 Durst 认为没有一些反对理论, 现在的写作理论家, 便不像他们在1984 时一 样, 百家争鸣, 在争议中不断发展 一 好像教育法 《没有儿童被遗下》, 这 个法规只强调文学性的写作, 其它理论家都认为这是一个错误的方向, 应该引 入多些创意性和表达性的写作教学。

整体来说, 这些回顾指出社会转变影响了写作研究的方向, 写作不单是作者个 人挣扎在纸笔上（或于键盘上）, 写作和写作教学与社会环境、文化和历史有 密切的关系。写作的研究和教学, 比较少关注有效教学 (Braddock et al. , 1963; Hillocks, 1986) , 还开始思考「为甚么」和「怎样」。 有关这个论题, 写作研究员会思考为甚么一个特定的教学方式, 在一富裕的郊 区行得通, 却在一穷困的市区的课室出现阻力; 或者史密夫女士于 203 室手舞 足蹈, 但在 204 室的锤斯女士却失败了。在未来二十年, 这些细微和不同背 景, 令写作研究变得更复杂和富挑战性, 也奠定下了写作的研究基础。

\section{参考书目}

Braddock, R., Lloyd-Jones, R., \& Schoer, L. (1963). Research in written composition. Champaign, IL: National Council of Teachers of English.

Hillocks, G., Jr. (1986). Research on written composition: New directions for teaching. Urbana, IL: National Conference on Research in English/ERIC Clearinghouse on Reading and Communications skills.

Smagorinsky, P. (Ed.). (2006). Research on composition: Multiple perspectives on two decades of change. New York: Teachers College Press and the National Conference on Research in Language and Literacy. 